\title{
ENGINEERING STUDENTS' BLENDED LEARNING IN HIGHER EDUCATION
}

\author{
Andreas Ahrens \\ Faculty of Engineering, \\ Department of Electrical Engineering and Computer Science, \\ Hochschule Wismar, University of Technology, Business and Design \\ Jel̦ena Zaščerinska \\ Centre for Education and Innovation Research \\ Natalia Andreeva \\ Immanuel Kant Baltic Federal University
}

\begin{abstract}
Blended learning in higher education has already become an indispensable tool in both university staff and students' daily life. A number of definitions of blended learning have been developed. However, these definitions mostly focus on the synergy of traditional and online instruction, thereby these definitions lack its main notion - blended learning. These othersided definitions do not contribute to the qualitative blended learning for the improvement of students' learning achievements. Aim of the present paper is to analyze and work out the definition of blended learning underpinning analysis of quality of blended learning for the improvement of students' learning achievements. The meaning of the key concepts of blended learning and students' learning achievements is studied. Moreover, the logical chain of analysis is shown: blended learning $\rightarrow$ students' learning achievements $\rightarrow$ empirical study within a multicultural environment. The results show that students' learning achievements after having been implemented the blended learning process have been enhanced. Directions of further research are proposed. The novel contribution of the paper is the definition of blended learning worked out by the paper's authors.
\end{abstract}

Keywords: Blended Learning, Engineering Students, Higher Education

\section{Introduction}

Blended learning in higher education has already become an indispensable tool in both university staff and students' daily life. Blended learning is a new learning form that combines the advantageous of traditional learning in lectures/seminars with innovative e-learning in a variety of Information and Communication technology's usage. A number of definitions of blended learning have been developed. However, in most cases these definitions represent the synergy of traditional and on-line instruction. Thereby, these definitions lack its main notion - blended learning. Therefore, existing definitions of blended learning, from the researchers' view, have to be reconsidered as these definitions do not contribute to qualitative blended learning for the improvement of students' learning achievements. In the present research, blended learning is differentiated from blended teaching. Teaching means training, instruction provided by the educator to the students in higher education. Further on, the terms educational process, training, instruction and educational 
act are employed synonymously in the present research. As blended learning is an individual process, it is considered as the synergy of formal (institutionalized), non-formal and informal processes. In comparison, the educational process, training and instruction in higher education are defined as the institutionalized process as it is organised according to a given set of laws and norms. Aim of the present paper is to analyze and work out the definition of blended learning underpinning analysis of quality of the blended learning process for the improvement of students' learning achievements. The meaning of the key concepts of blended learning and students' learning achievements is studied. Moreover, the analysis demonstrates how the key concepts are related to the idea of the higher education and shows a potential model for development, indicating how the steps of the process are related following a logical chain: blended learning $\rightarrow$ students' learning achievements $\rightarrow$ empirical study within a multicultural environment. The novel contribution of this paper is the definition of blended learning worked out by the paper's authors. Moreover, the quality of the blended learning process in a multicultural environment is analyzed. Our target population to generalize the model of blended learning in higher education is students. Our empirical results obtained within Baltic Summer School Technical Informatics and Information Technology organized by the Rostock University, Rostock, Germany, in the Baltic States (Lithuania, Latvia and Estonia) in 2011 and 2012 show that the students' learning achievements after having been implemented the blended learning process have been enhanced. The remaining part of this paper is organized as follows: Section 2 introduces blended learning and students' learning achievements in higher education. The associated results of an empirical study will be presented in Section 3.

Finally, some concluding remarks are provided in Section 4 followed by a short outlook on interesting topics for further work.

\section{Blended Learning}

Many researchers define blended learning as a combination of face-to-face (traditional classroom) and online instruction (Grgurovic, 2011; Qiu, Chen, 2011; Staker, M. Horn, 2012; Tucker, 2012). However, learning is learning, and instruction (teaching, training) is instruction. Hence, learning is neither teaching or instruction, or training. This differentiation between blended instruction and blended learning is highly significant as blended instruction (teaching, training) does not provide positive results in the improvement of students' learning achievements till blended learning is engaged.

In order to provide a proper definition of blended learning, the concept of the term definition should be discussed. In the present research, the term definition is considered as the statement of the phenomenon notion, elements and process. 
Thereby, a definition's components include notion, elements and process as depicted in Figure 1.

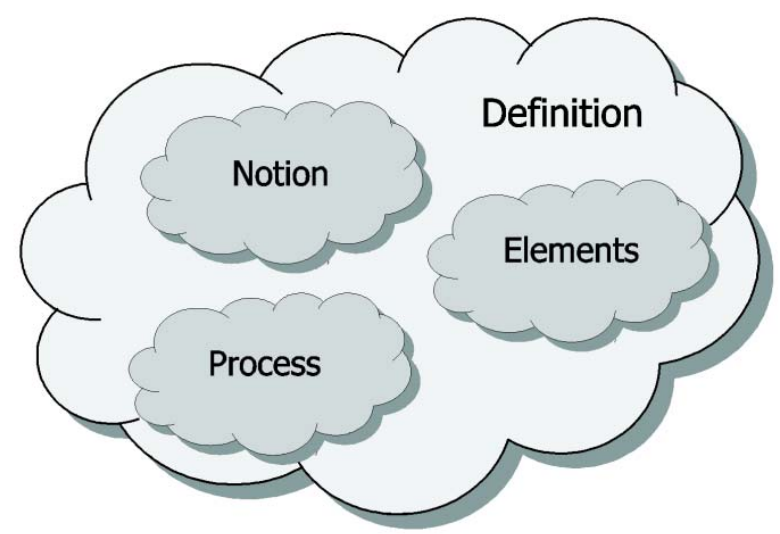

Figure 1. Definitions' Components

Further on, definitions are not static, they are in a state of process, change and development.

The authors of the present research start their defining blended learning from the learning analysis. In the present research, learning is defined as a purposefully organized or spontaneous individual process of students' improvement of his/her individual experience (knowledge, skills and attitudes) based on cognition. In comparison, teaching in higher education is defined as a purposefully organized joint process of educator's sharing experience (knowledge, skills and attitudes) with students. Then, the authors of the present contribution support the definition of blended (hybrid) learning as one of the approaches that is utilized to help students for meaningful learning via information and communication technologies suggested by Gecer and Dag (Gecer, Dag, 2004). Thus, blended learning is the combination of learning and e-Learning as depicted in Figure 2.

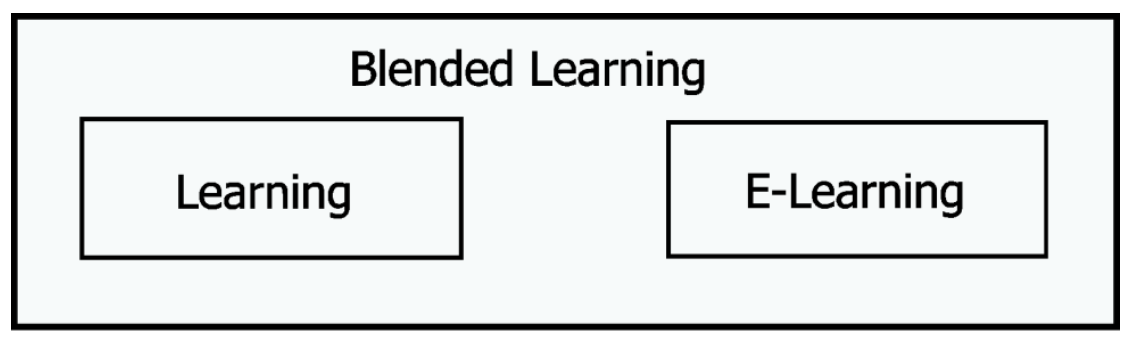

Figure 2. Elements of blended learning

E-Learning differs from learning by use of information and networking technologies in the process of cognition. As higher education is centred on research, e-Learning in higher education as demonstrated in Figure 3 includes use of

- university e-Libraries, 
- patent databases such as European Patent Office (EPO), US Patent and Trademark Office (PTO),

- bibliographic databases such as SciVerse Scopus (SCOPUS), Thomson Reuters, Education Resources Information Center (ERIC),

- research communities' networks such as www. researchgate.com, www.ResearcherID.com, etc.

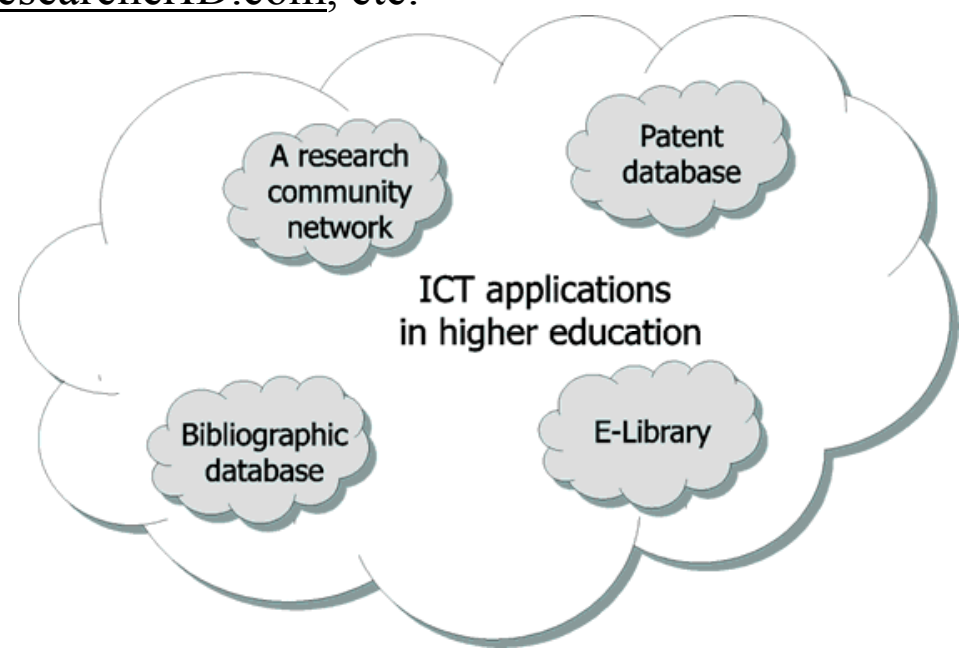

Figure 3. Use of information and networking technologies in e-Learning within higher education

A number of the models of the process of blended learning have been proposed (Porumb, Orza, Vlaicu, Porumb, Hoza, 2011). The models' authors suggest that blended learning proceeds in the educational act of two main phases (Porumb, Orza, Vlaicu, Porumb, Hoza, 2011) as shown in Figure 4:

- regular teaching in Phase 1 and

- Internet-based learning in Phase 2.

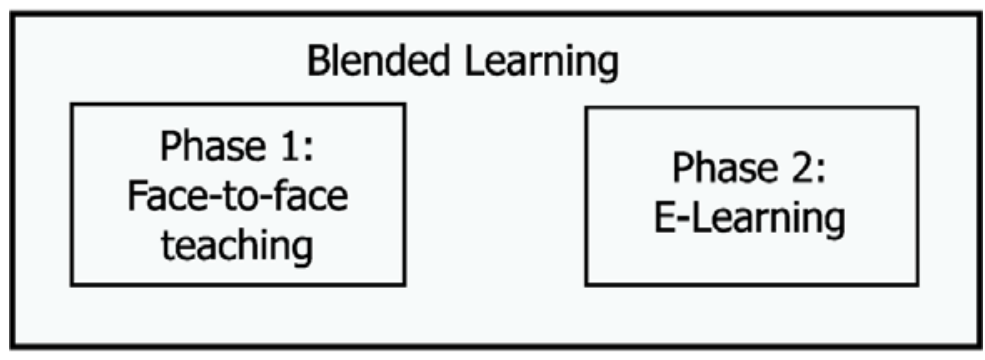

Figure 4. The educational act of blended learning

Analysis of these particular models of the process of blended learning by the authors of the present contribution shows that these models include both blended learning and teaching (instruction, training). As the paper's authors differentiated blended learning from blended teaching, further only the process of blended learning is considered.

In the present research, the process of blended learning proceeds as a cycle. The authors of the present paper propose the cycle of the process of blended learning 
of three phases demonstrated in Figure 5, namely, preparation in Phase 1, implementation in Phase 2 and analysis in Phase 3.

Phase 1 Preparation is aimed at planning the implementation of blended learning, choosing forms of information compilation and using resources for the implementation of blended learning. Phase 2 Implementation is focused on analysis of an open problem situation and search for a solution. Phase 3 Analysis includes evaluation of the blended learning results and elaboration of further perspectives.
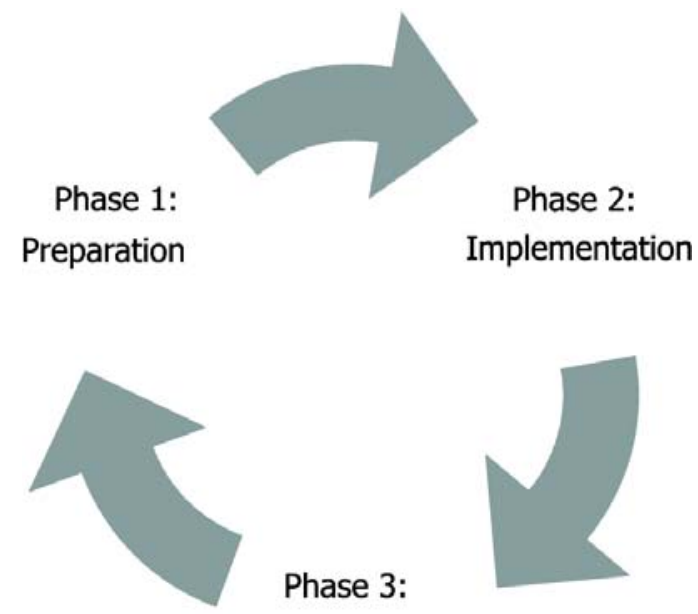

Analysis

Figure 5. The cycle of the process of blended learning

\section{Empirical Rasearch}

The research design within the present research comprises the research methodology, the sample of the present research and the research findings considered.

The research question is as follows: has the process of blended learning been qualitative? Therefore, the research is aimed at analyzing the quality of the process of blended learning.

Interpretative research paradigm which corresponds to the nature of humanistic pedagogy (Lūka, 2008) has been determined. Interpretative paradigm is characterized by the researchers' practical interest in the research question (Cohen, Manion, 2004).

Checking the quality of pedagogic interventions and organizational changes in complex and constantly self-regenerating environments employs the qualitative evaluation research (Flick, 2004). Therefore, the qualitative evaluation research has been used in the empirical study.

The qualitative evaluation research is aimed at examining the quality of the process of blended learning. Therein, quality of the process of blended learning is regarded as the improvement of students' learning achievements. The authors of the present contribution define students' learning achievements as 
quantitative evaluation of qualitative level of students' learning results made by the educator with use of marks or grades. Further on, the process of blended learning is qualitative if the inputs (the process of blended learning) produce the maximum output (students' learning achievements) (Commission of the European Communities, 2006). Therein, students' learning achievements are the criterion of the quality of the process of blended learning.

The present empirical study employs the qualitatively oriented research. Traditionally, the qualitatively oriented research uses only few cases (Mayring, 2007). Use of only few cases in the qualitatively oriented research is opposed to the quantitatively oriented research which usually demands on a big sample of data to be collected. Moreover, the cases themselves are not of interest, only the conclusions and transfers drawn from these cases (Mayring, 2007). Selecting the cases for the case study comprises use of information-oriented sampling (Flyvbjerg, 2006). This is because an average case is often not the richest in information. In addition, it is often more important to clarify the deeper causes behind a given problem and its consequences than to describe the symptoms of the problem and how frequently they occur (Flyvbjerg, 2006).

The empirical study consisted of the following stages:

- pre- and post-surveys' data collection in 2011 and 2012,

- data processing, analysis and data interpretation,

- analysis of the results and

- elaboration of conclusions and directions of further research.

The present empirical study was conducted within the Academic Presentation course in the Seventh Baltic Summer School Technical Informatics and Information Technology at Riga Technical University, Riga, Latvia, August 1227, 2011 and Eighth Baltic Summer School Technical Informatics and Information Technology at the University of Tartu, Tartu, Estonia, July 28 August 12, 2012. The sample involved 18 respondents:

- 11 engineering students in 2011 and

- seven engineering students in 2012.

All 18 engineering students have got Bachelor or Master Degree in different fields of computer sciences and working experience in different fields. These 18 engineering students represent different cultural backgrounds and diverse educational approaches from different countries, namely, Latvia, Lithuania, Estonia, Belarus, Mongolia, China, Morocco and Pakistan. Whereas cultural similarity aids mutual understanding between people (Robbins, 2007), the students' different cultural and educational backgrounds contribute to successful learning. These diverse backgrounds become an instrument of bringing the students together more closely under certain conditions such as appropriate materials, teaching/learning methods and forms, motivation and friendly positioning of the educator (Abasheva, 2010). Therein, the sample of 18 engineering students is multicultural. 
This International Summer School offers special courses to support internationalization of education and cooperation among the universities of the Baltic Sea Region. The aims of Baltic Summer Schools Technical Informatics and Information Technology are preparation for international Master and Ph.D. programmes in Germany, further specialization in computer science and information technology and learning in a simulated environment. The Baltic Summer School comprises the Academic Presentation course.

The aim of the Academic Presentation course is to improve engineering students' communicative competence in English for Academic Purposes for their participation in international research activities whereas the objectives of the Academic Presentation course are to widen the engineering students' social experience: experience in social interaction and experience in cognitive activity. In order to determine the developmental dynamics of each engineering student's learning achievements in the Academic Presentation course, the qualitative evaluation research included the comparison of the pre-survey and post-survey results of each engineering student's learning achievements.

The comparison revealed that the engineering students' learning achievements in 2011 had increased to 10 students as shown in Figure 6.

The comparison revealed that the engineering students' learning achievements in 2012 had increased to five engineering students as demonstrated in Figure 7.

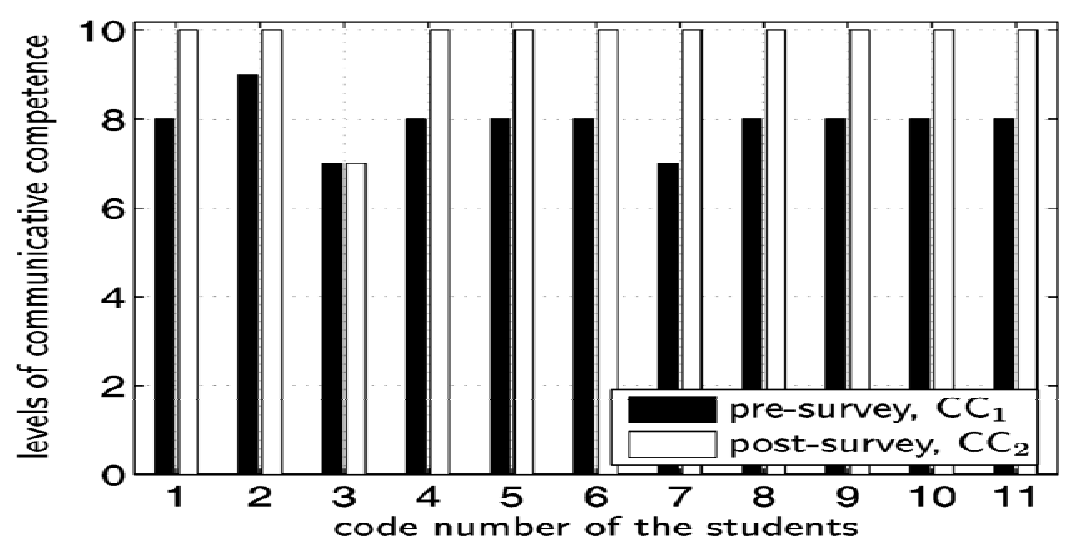

Figure 6. Inter-connections of the pre-survey and post-survey between levels of each student's learning achievements.

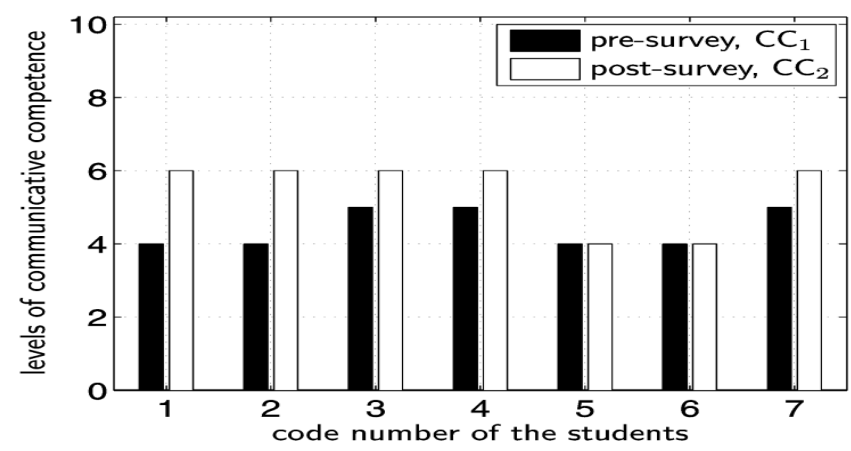

Figure 7. Inter-connections of the pre-survey and post-survey between levels of each student's learning achievements 
In Figure 6 and 7

- the vertical numbers mean 10 levels of learning achievements,

- the horizontal numbers present the code number of the engineering students who participated in the pre- and post-surveys,

- Code $\mathrm{CC}_{1}$ shows the pre-survey's results of the engineering students' learning achievements and

- Code $\mathrm{CC}_{2}$ shows the post-survey's results of the engineering students' learning achievements.

In 2011, the post-survey's results demonstrate Level 9 of the engineering students' learning achievements in the Academic Presentation course in comparison with Level 8 in the pre-survey. In 2012, the post-survey's results in 2012 demonstrate Level 5 of the engineering students' learning achievements in the Academic Presentation course in comparison with Level 4 in the pre-survey. Finally, the Mean results of the descriptive statistics show that the level of the engineering students' learning achievements in the Academic Presentation course in 2011 and 2012 has positively changed as demonstrated in Table 1.

Table 1

Mean analysis of the pre-and post-surveys

\begin{tabular}{|l|c|c|}
\hline Quality criterion & Mean in the Pre-survey & $\begin{array}{l}\text { Mean in the Post- } \\
\text { survey }\end{array}$ \\
\hline $\begin{array}{l}\text { Students' learning achievements in } \\
2011\end{array}$ & 7,9 & 9,7 \\
\hline $\begin{array}{l}\text { Students' learning achievements in } \\
2012\end{array}$ & 4,4 & 5,4 \\
\hline
\end{tabular}

Hence, considering judgment to be part of the art of statistics (Gigerenzer, 2004), the conclusion has been drawn that the process of blended learning in the Academic Presentation course in 2011 and 2012 influenced the development of the engineering students' learning achievements. This positive influence is demonstrated by the difference between the levels of the engineering students' learning achievements in the pre- and post-survey.

\section{Conslusions}

The findings of the present research allow drawing conclusions on the quality of the process of blended learning applied to enhance learning achievements of the engineering students in the Academic Presentation course within the Seventh and Eighth Baltic Summer School Technical Informatics and Information Technology.

Regarding quality assurance it is evident that the engineering students' learning achievements has been improved. The engineering students have gained their experience during the process of blended learning implemented for the 
improvement of their learning achievements. This experience changed into the means of gaining new opportunities and advantages. Irrespective of levels in the engineering students' initial learning achievements, the process of blended learning has become an effective means of acquiring experience by the engineering students and has served as a motivating factor to continue learning in order to increase their learning achievements. The provided support for engineering students, namely, the process of blended learning, in the Academic Presentation course resulted in the improved engineering students' learning achievements. Therein, the process of blended learning in the Academic Presentation course has contributed to the improvement of the students' learning achievements.

Thus, the conclusion can be drawn that the process of blended learning in the Academic Presentation course enhances engineering students' learning achievements. Hence, the process of blended learning in the Academic Presentation course for the improvement of students' learning achievements influences and determines the students' success or failure for acquiring higher education and profession as depicted in Figure 8.

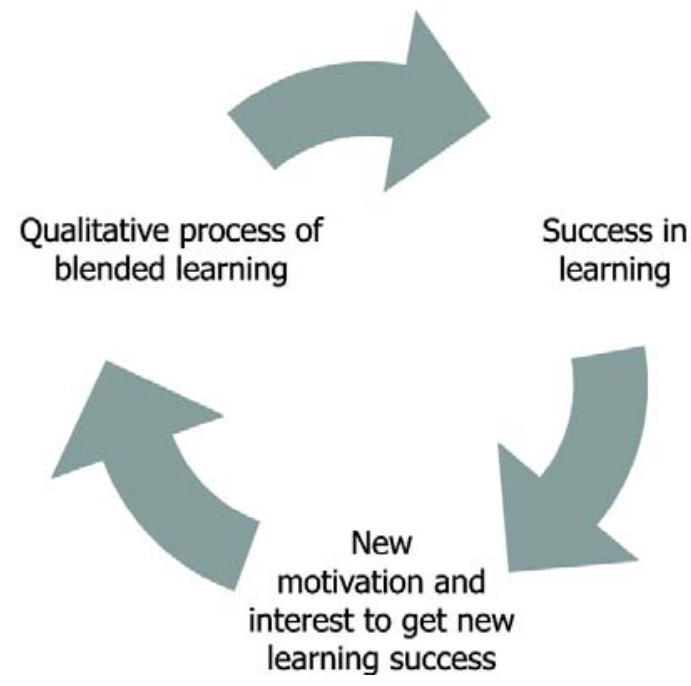

Figure 8. Successful process of blended learning for the improvement of students' learning achievements in higher education

The present research has limitations. The inter-connections between the process of blended learning and students' learning achievements have been set. A limitation is the empirical study conducted by involving the students of one tertiary institution. Therein, the results of the study cannot be representative for the whole tertiary area. Nevertheless, the results of the research - the definition of blended learning, students' learning achievements and the qualitative evaluation research design to examine the quality of the process of blended learning for the improvement of students' learning achievements - may be used as a basis of the development of engineering students' learning achievements of 
other tertiary institutions. If the results of other tertiary institutions had been available for analysis, different results could have been attained. There is a possibility to continue the study.

The search for relevant methods for evaluation of students' learning outcomes influenced by blended learning is proposed. Empirical studies on students' learning outcomes in blended learning in other tertiary institutions could be investigated. A comparative research of different countries could be carried out, too.

\section{Kopsavilkums \\ Summary}

Jauktās mācīšanās augstākajā izglîtībā jau ir kḷuvis par neaizstājamo līdzekli gan universitātes personālam gan studentiem ikdienas dzīvē. Vairākās definīcijas , jauktā mācǐšanās" ir izstrādāti. Tomēr šīs definīcijas, galvenokārt, tika koncentrēti uz tradicionālās un tiešsaistes mācišanās sinerǵiju, tādējādi šīs definīcijās trūkst galvenā ideja - jauktā mācišanās. Šie citu pušu definīcijas neveicina kvalitatīvu jauktu mācīšanu studentu mācīšanās sasniegumu uzlabošanā .

Mērķis šajā rakstā ir analizēt un izstrādāt definīciju ,jauktā mācīšanās”, pamatojot jauktās mācīšanās kvalitātes analīzi studentu mācīšanās sasniegumu uzlabošanai. Galveno jēdzienu ,jauktā mācīšanās” un „studentu mācīšanās sasniegumi” nozīme tiek pētīta. Turklāt, analīzes log̣iskā ķēde tiek parādīta: $\rightarrow$ jauktā mācīšanās studentu mācǐšanās sasniegumi $\rightarrow$ empīriskais pētījums daudzkultūru vides ietvaros.

Rezultāti rāda, ka studentu mācišsanās sasniegumi pēc tam, kad tika īstenots jauktās mācǐšanās apmācības process, ir uzlaboti. Virzieni turpmākiem pētījumiem ir izstrādāti. Raksta inovatīvais ieguldījums ir jauktās mācīšanās definīcija, ko izstrādājusi raksta autori.

\section{Bibliography}

1. Abasheva, C. (2010). Specifics of the English Language Education in the Study Groups with Different Mother Tongues. In M. Marnauza (Ed), 5th International Scientific Conference Theory for Practice in the Education of Contemporary Society of Riga Teacher Training and Educational Management Academy. Riga, Latvia. 428-431.p.

2. Staker, Heather, Horn, Michael. (2012). Classifying K-12 Blended Learning. Innosight Institute.

3. Tucker, C. (2012). Blended Learning in Grades 4-12: Leveraging the Power of Technology to Create Student-Centered Classrooms. Corwin.

4. Cohen, Louis, Manion, Lawrence, et al. (2003). Research Methods in Education. London, New York: Routledge/Falmer Taylor \& Francis Group.

5. Commission of the European Communities. (2006). Efficiency and Equity in European Education and Training Systems. Communication from the Commission to the Council and to the European Parliament, Brussels.

6. Flick, U. (2004). Design and Process in Qualitative Research. U. Flick, E. Von Kardoff and I. Steine (Eds) A Companion to Qualitative Research, SAGE, Glasgow UK 
7. Flyvbjerg, B. (2006). Five Misunderstandings About Case-Study Research. Qualitative Inquiry, 12(2) 219-245.

8. Gecer, Aynur, Dag, Funda. (2012). A Blended Learning Experience. Educational Sciences: Theory and Practice,12(1), 438-442.

9. Gigerenzer, Gerd, (2004). Mindless Statistics. The Journal of Socio-Economics, 33(5), 587-606.

10. Grgurovic, M. (2011). Blended Learning in an ESL Class: A Case Study. CALICO Journal, 29(1), Sep 2011, 100-117.

11. Lūka, I. (2008). Development of Students' ESP Competence and Educator's Professional Activity in Tertiary Level Tourism Studies. Proceedings of ATEE Spring University Conference Teacher of the 21st Century: Quality Education for Quality Teaching, University of Latvia, Riga, Latvia, 689-697.

12. Mayring, P. (2007). On Generalization in Qualitatively Oriented Research. Forum Qualitative Sozialforschung / Forum: Qualitative Social Research, 8(3), Art. 26, 1-8.

13. Qiu, M., Chen, L. (2011). A Problem-based Learning Approach to Teaching an Advanced Software Engineering Course, Proc. $2^{\text {nd }}$ International Workshop on Education Technology and Computer Science, 252-255.

14. Porumb, Sanda, Orza, Bogdan, Vlaicu, Aurel, Porumb, Cosmin, Hoza, Ioan. (2011). Cloud Computing and its Application to Blended Learning in Engineering. CLOUD COMPUTING 2011: The Second International Conference on Cloud Computing, GRIDs, and Virtualization, IARIA, 173-180.

15. Robbins, D. (2007). Vygotsky's and Leontiev's Non-classical Psychology related to second Language Acquisition. International Nordic-Baltic Conference of FIPLV Innovations in Language Teaching and Learning in the Multicultural Context, Rīga: SIA "Izglītības solii", Latvia, 47-57.

\begin{tabular}{|r|l|}
\hline $\begin{array}{r}\text { Andreas } \\
\text { Ahrens }\end{array}$ & Faculty of Engineering, Department of \\
& Electrical Engineering and Computer \\
& Science, Hochschule Wismar, \\
& University of Technology, Business and \\
& Design \\
& Philipp-Müller-Straße 14, 23952 Wismar, \\
& Germany \\
& E-mail:andreas.ahrens@hs-wismar.de \\
& Phone: +49 3841 753330 \\
& Fax:+49 3841 753130 \\
\hline Zašena & Centre for Education and Innovation \\
& Research \\
& Kurzemes prospekts 114, Rīga, LV-1069, \\
& Latvia \\
& E-mail: knezna@inbox.lv \\
& Phone: +371 29435142 \\
\hline Natalia & Immanuel Kant Baltic Federal University \\
Andreeva & Nevskogo street 14, 236041 Kaliningrad, \\
& Russia \\
& E-mail: andreeva_natalia@list.ru \\
& Phone: +7 4012 338217
\end{tabular}

